\title{
Cryptosporidium scrofarum n. sp. (Apicomplexa: Cryptosporidiidae) in domestic pigs (Sus scrofa)
}

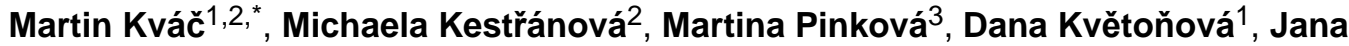 \\ Kalinová1, Pavla Wagnerová ${ }^{1,2}$, Michaela Kotková ${ }^{1}$, Jiří Vítovec ${ }^{2}$, Oleg Ditrich ${ }^{1}$, John \\ McEvoy $^{4}$, Brianna Stenger ${ }^{4}$, and Bohumil Sak ${ }^{1}$ \\ ${ }^{1}$ Institute of Parasitology, Biology Centre of the Academy of Sciences of the Czech Republic, \\ v.v.i., České Budějovice, Czech Republic \\ ${ }^{2}$ Faculty of Agriculture, University of South Bohemia in České Budějovice, Czech Republic \\ ${ }^{3}$ Institute of Animal Physiology and Genetics, Academy of Sciences of the Czech Republic, \\ Czech Republic \\ ${ }^{4}$ Veterinary and Microbiological Sciences Department, North Dakota State University, Fargo, USA
}

\begin{abstract}
We describe the morphological, biological, and molecular characteristics of Cryptosporidium pig genotype II and propose the species name Cryptosporidium scrofarum n. sp. to reflect its prevalence in adult pigs worldwide. Oocysts of $C$. scrofarum are morphologically indistinguishable from $C$. parvum, measuring 4.81-5.96 $\mu$ m (mean $=5.16) \times 4.23-5.29 \mu \mathrm{m}$ (mean $=4.83)$ with a length to width ratio of $1.07 \pm 0.06(\mathrm{n}=400)$. Oocysts of $C$. scrofarum obtained from a naturally infected pig were infectious for 8 -week-old pigs but not 4 -week-old pigs. The prepatent period in 8-week-old Cryptosporidium-naive pigs was 4-6 days and the patent period was longer than 30 days. The infection intensity of $C$. scrofarum in pigs was generally low, in the range 250-4000 oocysts per gram of faeces. Infected pigs showed no clinical signs of cryptosporidiosis and no pathology was detected. Cryptosporidium scrofarum was not infectious for adult SCID mice, adult BALB c mice, Mongolian gerbils (Meriones unguiculatus), southern multimammate mice (Mastomys coucha), yellow-necked mice (Apodemus flavicollis), or guinea pigs (Cavia porcellus). Phylogenetic analyses based on Small subunit rRNA, actin, and heat shock protein 70 gene sequences revealed that $C$. scrofarum is genetically distinct from all known Cryptosporidium species.
\end{abstract}

\section{Keywords}

Cryptosporidium scrofarum; Taxonomy; Morphology; Molecular analyses; Transmission studies; Cryptosporidium pig genotype II

\footnotetext{
(C) 2012 Elsevier B.V. All rights reserved.

*Address for correspondence: Kváč Martin; Biology Centre of the Academy of Sciences of the Czech Republic, v.v.i.; Branišovská 31; 37005 České Budějovice; Czech Republic. telephone: +420387775419; fax: +420385310388; kvac@ paru.cas.cz.

Publisher's Disclaimer: This is a PDF file of an unedited manuscript that has been accepted for publication. As a service to our customers we are providing this early version of the manuscript. The manuscript will undergo copyediting, typesetting, and review of the resulting proof before it is published in its final citable form. Please note that during the production process errors may be discovered which could affect the content, and all legal disclaimers that apply to the journal pertain.
} 


\section{Introduction}

Porcine cryptosporidiosis, which was first described in the USA (Bergeland, 1977; Kennedy et al., 1977), has been reported to occur worldwide. Cryptosporidium parvum was initially considered to be the causal agent based on experimental infection studies undertaken in the 1980s (Moon and Bemrick, 1981; Tzipori et al., 1982; Vítovec and Koudela, 1992).

Subsequent molecular epidemiology and experimental infection studies revealed the susceptibility of pigs to a number of species including $C$. parvum, $C$. hominis, $C$. suis, $C$. felis, and C. meleagridis. Cryptosporidium muris and C. tyzzeri also have been isolated from pigs; however, infectivity could not be confirmed experimentally (Kváč et al., 2012). In addition to the named species, genotypes including Cryptosporidium sp. Eire w65.5, Cryptosporidium rat genotype, C. suis-like, and Cryptosporidium pig genotype II, have been reported in pigs (Langkjær et al., 2007; Zintl et al., 2007). Among these species and genotypes, only C. suis (Morgan et al., 1999; Ryan et al., 2004) and Cryptosporidium pig genotype II appear to be adapted to pigs. Ryan et al. (2003) identified Cryptosporidium pig genotype II based on its unique small subunit rRNA (SSU) gene sequence; however, no biological data have been reported.

Cryptosporidium oocysts have been detected in the faeces or slurry of pigs in Australia (Johnson et al., 2008; McCarthy et al., 2008; Ryan et al., 2003), Brazil (Fiuza et al., 2011), Canada (Budu-Amoako et al., 2012; Farzan et al., 2011; Guselle et al., 2003; Olson et al., 1997; Sanford, 1987), China (Chen et al., 2011; Wang et al., 2010; Yin et al., 2011), Croatia (Bilic and Bilkei, 2006), Czech Republic (Jeníková et al., 2011; Kváč et al., 2009a,c; Vítovec et al., 2006), Denmark (Langkjær et al., 2007; Maddox-Hyttel et al., 2006), England (Featherstone et al., 2010), Germany (Epe et al., 2004; Wieler et al., 2001), Ireland (Zintl et al., 2007), Italy (Canestri Trotti et al., 1984), Japan (Izumiyama et al., 2001), Korea (Rhee et al., 1991), Nigeria (Yatswako et al., 2007), Norway (Hamnes et al., 2007), Spain (Nunez et al., 2003; Quilez et al., 1996; Reinoso and Becares, 2008; Villacorta et al., 1991), Switzerland (Ebeid et al., 2003), Taiwan (Hsu et al., 2008), Trinidad and Tobago (Adesiyun et al., 2001), and USA (Atwill et al., 1997; Bergeland, 1977; Kennedy et al., 1977; Tacal et al., 1987; Xiao et al., 1994; Xiao et al., 2006). Cryptosporidium pig genotype II was reported in domestic pigs in nine countries. In addition, wild boars, calves, marine fish, and humans have been reported as natural hosts of this genotype (Table 1) (Kváč et al., 2009a,b,c; Němejc et al., 2012; Ng et al., 2011; Reid et al., 2010).

Differences in the age of pigs infected with $C$. suis and Cryptosporidium pig genotype II have been reported recently. Cryptosporidium suis appears to infect all age categories of pigs, though prevalence is lower in older pigs. Conversely, Cryptosporidium pig genotype II appears to be specific for older pigs (Jeníková et al., 2011; Kváč et al., 2009a,c; Langkjær et al., 2007; Němejc et al., 2012), with a much lower prevalence observed in younger age categories, primarily in pre-weaned piglets (Table 1).

No other names have been used for Cryptosporidium pig genotype II in publications or GenBank. There are 49 sequences for 6 genes available in GenBank (43, 2, 1, 1, 1, and 1 for the SSU, actin, HSP70 (heat shock protein 70), COWP (Cryptosporidium oocyst wall protein), $15 \mathrm{kDa}$ and $23 \mathrm{kDa}$ sporozoite surface antigen, respectively.

We undertook this study to examine the experimental transmission, oocyst morphology, and molecular characteristics of Cryptosporidium pig genotype II. Based on the collective data from this and other studies, which show that Cryptosporidium pig genotype II is genetically distinct from known Cryptosporidium species and uniquely adapted to adult pigs, we propose the species name Cryptosporidium scrofarum n. sp. 


\section{Materials and Methods}

\subsection{Source of oocysts for transmission studies}

Faecal samples from 3-15-week-old pigs kept on a commercial farm were screened for Cryptosporidium by microscopic examination of faecal smears stained with aniline-carbolmethyl violet (ACMV) (Miláček and Vítovec, 1985) and PCR. The naturally infected 9week-old pigs (Sus scrofa) were purchased and separately housed. Faecal specimens were collected daily and stored in a $2.5 \%$ potassium dichromate solution. Cryptosporidium oocysts were purified for morphology, phylogeny, and infectivity analyses using sucrose gradient (Arrowood and Sterling, 1987) and caesium chloride gradient centrifugation (Kilani and Sekla, 1987). Purified oocysts were stored for up to 4 weeks in PBS with antimycotics and antibiotics at $4^{\circ} \mathrm{C}$ in darkness. The parasite was confirmed to be the Cryptosporidium pig genotype II by sequence analysis of the SSU gene using previously described methods (Jeníková et al., 2011; Jiang et al., 2005). The number of oocysts administered to animals was determined by hemacytometer counting. The viability of oocysts was examined using an assay previously described by Kváč et al. (2007a). Briefly: the viability of oocysts was determined by propidium iodide (PI) staining (Sauch et al., 1991). Examined oocysts were washed in distilled water (DW; $1 \times 10^{5}$ oocysts in $100 \mu \mathrm{l}$ ) and mixed with $10 \mu \mathrm{l}$ of PI ( $1 \%$ solution, SIGMA). After $30 \mathrm{~min}$ of incubation at room temperature in the dark, the oocysts were washed twice with DW. Oocyst viability was examined using fluorescence microscopy (filter $420 \mathrm{~nm}$, Olympus IX70). A total of 5×100 oocysts was counted.

\subsection{Oocyst morphology}

Oocysts were examined using differential interference contrast (DIC) microscopy, brightfield microscopy following ACMV staining, and epifluorescence microscopy following labelling with genus-specific FITC-conjugated antibodies (Cryptosporidium IF Test, Crypto cel, Medac) (Olympus IX70 microscope; Olympus CZ, Czech Republic). Morphology and morphometry were determined using digital analysis of images (M.I.C. Quick Photo Pro v.1.2 software; Optical Service, Czech Republic) collected using an Olympus Camedia C 5060 WIDEZOOM 5.1 megapixel digital camera (Optical Service). A $20 \mu \mathrm{l}$ aliquot containing 100,000 purified oocysts was used for each measurement. Length and width of oocysts $(n=100)$ were measured under DIC at $\times 1,000$ magnification. The shape index and length-to-width ratio of each oocyst was calculated. As a control, the morphometry of $C$. parvum $(\mathrm{n}=100)$ from a naturally infected 30-day-old Holstein calf was measured by the same person using the same microscope. A photomicrograph of $C$. scrofarum oocysts observed by DIC, ACMV and IFA was deposited as a phototype at the Institute of Parasitology, Biology Centre of the Academy of Sciences of the Czech Republic.

\subsection{DNA extraction and molecular analyses}

Total DNA was extracted from $200 \mathrm{mg}$ of faeces, $50 \mu \mathrm{l}$ of purified oocysts, or $200 \mathrm{mg}$ of tissue by bead disruption for $60 \mathrm{~s}$ at $5.5 \mathrm{~m} / \mathrm{s}$ using $0.5 \mathrm{~mm}$ glass beads in a FastPrep ${ }^{\circledR}-24$ Instrument (MP Biomedicals, CA, USA) followed by isolation/purification using a commercially available kit in accordance with the manufacturer's instructions (QIAamp! DNA Stool Mini Kit or DNeasy! Blood \& Tissue Kit, Qiagen, Hilden, Germany). Purified DNA was stored at $-20^{\circ} \mathrm{C}$ prior to being used for PCR.

A nested PCR approach was used to amplify a region of the SSU ( $830 \mathrm{bp}$; Jiang et al., 2005; Xiao et al., 1999) and HSP70 genes ( 325 bp; Morgan et al., 2001). A semi-nested PCR was used to amplify the actin gene ( $619 \mathrm{bp}$; this study). Three primers were designed using the pig genotype II sequence in Genbank (EF012374). The forward primer for both primary and secondary reactions was ScrofActinFA (TGT AGG TGA CGA GGC TCA ATC CAA). ScrofActinRA (ATC GAT TGG AAA GTG GTC TCG CCA) and 
ScrofActinRB (TTC TGG GCA CCT AAA TCT CTC GCT) were used as reverse primers in the primary and secondary reactions, respectively. The primary PCR reactions were carried out in a volume of $100 \mu \mathrm{l}$ containing $1 \mu \mathrm{l}$ of DNA template (or water as a negative control), $1 \mathrm{X}$ PCR buffer, $1.5 \mathrm{mM} \mathrm{MgCl} 2,200 \mu \mathrm{M}$ dNTPs, $0.2 \mu \mathrm{M}$ of each primer, and $2.5 \mathrm{U}$ of Taq DNA polymerase (Promega GoTaq Flexi). Secondary reactions were carried out under similar conditions with the exception that $2 \mu$ of primary product was used as template. PCR reactions were run in a thermo cycler (Eppendorf Mastercycler gradient) with an initial denaturation of $94^{\circ} \mathrm{C}$ for $5 \mathrm{~min}$, followed by 35 cycles of $94^{\circ} \mathrm{C}$ for $45 \mathrm{~s}, 57^{\circ} \mathrm{C}$ for $45 \mathrm{~s}, 72^{\circ} \mathrm{C}$ for $1 \mathrm{~min}$. A final elongation step of $72^{\circ} \mathrm{C}$ for $10 \mathrm{~min}$ was included to ensure complete extension of amplified products. Conditions were the same for both primary and secondary reactions. In order to distinguish $C$. scrofarum from $C$. suis in mixed infections, a C. scrofarum-specific forward primer was used in secondary PCR amplifications (Jeníková et al., 2011). DNA from C. scrofarum and $C$. hominis were used as positive and negative controls, respectively. Secondary PCR products were detected by agarose gel $(1.5 \%)$ electrophoresis, visualized by ethidium bromide staining $(0.2 \mu \mathrm{g} / \mathrm{ml})$, and extracted using QIAquick! Gel Extraction Kit (Qiagen). Purified secondary products were sequenced in both directions with an ABI 3130 genetic analyser (Applied Biosystems, Foster City, CA) using the secondary PCR primers and the BigDye1 Terminator V3.1 cycle sequencing kit (Applied Biosystems, Foster City, California) in $10 \mu$ reactions. The identity of $C$. parvum used for morphological analyses was verified using sequencing of SSU (data not shown).

\subsection{Phylogenetic analyses}

The nucleotide sequences of each gene obtained in this study were edited using the programme ChromasPro 1.5 (Technelysium, Pty, Ltd.) and were aligned with each other and with reference sequences from GenBank using ClustalX 2.0.6. Alignment adjustments were made manually to remove artificial gaps using BioEdit. Phylogenetic analyses were performed using the software MEGA5 (Tamura et al., 2011). Neighbour joining (NJ), maximum parsimony (MP), and maximum likelihood (ML) trees were constructed. All ambiguous positions were removed for each sequence pair. The reliability of branches in trees was assessed using the bootstrap analysis with 1000 pseudo-replicates, with values above 50\% reported. Phylograms were drawn using the MEGA5 and were manually adjusted using CorelDrawX5. SSU, actin, and HSP70 sequences have been deposited in GenBank under the accession numbers JX424840, JX424841, and JX424842, respectively.

\subsection{Transmission studies}

2.5.1. Animals-Five 8-week-old adult SCID mice (strain C.B-17), BALBc mice (Charles River, Germany), Mongolian gerbils (Meriones unguiculatus) (Charles River, Germany), southern multimammate mice (Mastomys coucha), yellow-necked mice (Apodemus flavicollis), guinea pigs (Cavia porcellus) (Institute of Parasitology, Biology Centre of the Academy of Sciences of the Czech Republic, Czech Republic), and 4- and 8-week-old pigs (Sus scrofa) (3 animals per group; purchased from the farm operated by the Faculty of Agriculture, University of South Bohemia in České Budějovice, Czech Republic) were used for experimental infection studies.

2.5.2. Experimental design-To prevent environmental contamination with oocysts, laboratory rodents were housed in plastic cages with sterilized wood-chip bedding situated in flexible film isolators (BEM, Znojmo, Czech Republic) with high-efficiency particulate air filters. The mice were supplied with a sterilized diet (TOP-VELAZ, Prague, Czech Republic) and water ad libitum.

Pigs were individually housed in $5 \mathrm{~m}^{2}$ pens with concrete walls and floor in an isolated building. Water and feeding mixture were available ad libitum. Rodents (five animals per 
group) were each inoculated orally by stomach tube with 1,000,000 purified oocysts suspended in $200 \mu \mathrm{l}$ of $\mathrm{dH}_{2} \mathrm{O}$. Pigs (three animals in each category) received the same infection dose in a $20 \mathrm{ml}$ suspension via syringe.

Faecal samples from all experimental animals were collected daily for 30 days post infection (DPI). Samples were stained with aniline-carbol-methyl violet (Miláček and Vítovec, 1985) and the presence of Cryptosporidium specific DNA was confirmed using nested PCR targeting the SSU gene. Infection intensity was reported as the number of oocysts per gram (OPG) of faeces as previously described (Kváč et al., 2007b).

2.5.3. Clinical and pathomorphological examinations-A complete examination of all gastrointestinal organs was conducted at necropsy. Tissue specimens of the gastrointestinal tract were sampled and processed for histology according to Kváč and Vítovec (2003) and for PCR analyses (see chapter 2.3.). Histology sections were stained with haematoxylin and eosin (HE), Wolbach's modified Giemsa stain, alcian blue, and genus-specific FITC conjugated monoclonal antibodies targeting Cryptosporidium oocyst wall antigens (Cryptosporidium IF Test, Crypto cel, Medac).

2.5.4. Animal care-Animal caretakers wore new disposable coveralls, shoe covers, and gloves every time they entered the buildings. All wood-chip bedding, pig faeces, and disposable protective clothing were sealed in plastic bags, removed from the buildings and incinerated. All housing, feeding, and experimental procedures involving pigs, laboratory mice of different strains, Mongolian gerbils, southern multimammate mice, yellow-necked mice, and guinea pigs were conducted under protocols approved by the Institute of Parasitology, Biology Centre of the Academy of Sciences of the Czech Republic and Institute and National Committees (Protocol No. 071/2010).

\section{Results}

\subsection{Experimental transmission studies}

Cryptosporidium scrofarum was not detected by microscopy or PCR in the faeces of 4week-old pigs following experimental infection. Conversely, sporadic oocyst shedding was detected in 8-week-old pigs beginning at 6-7 DPI and continuing for the duration of the study. Cryptosporidium scrofarum DNA was detectable in faeces by PCR beginning at 3 DPI and continuing for the duration of the study. Infection intensity was generally less than 2000 oocysts per gram of faeces (Figure 1). Infected pigs showed no clinical signs of disease and pigs necropsied at 30 DPI showed no macroscopic signs of intestinal cryptosporidiosis. Histological examination of the gastrointestinal tract of animals infected with $C$. scrofarum revealed the presence of developmental stages primarily attached to the microvillar border along small intestine with a predilection for the jejunum and ileum. The ratio of infected to non-infected glands in in the jejunum and ileum was approximately 1:200. The proportion of infected glands was much lower or developmental stages were absent in other parts of the small and large intestine. However, C. scrofarum DNA was detected by PCR (Table 2). No pathological changes were observed.

Cryptosporidium scrofarum was not detected by microscopy or PCR in the faeces of Mus musculus (SCID and BALB/c), Meriones unguiculatus, Mastomys coucha, Apodemus flavicollis, or Cavia porcellus following experimental infection. Histological and molecular examination of gastrointestinal tract tissue from these rodents did not reveal the presence of Cryptosporidium developmental stages. 


\subsection{Molecular characterization}

Isolates from naturally and experimentally infected pigs shared $100 \%$ sequence identity at the SSU, actin, and HSP70 loci. SSU and HSP70 sequences were identical to GenBank sequences EU331243 and DQ833282, respectively. The actin sequence was identical to a sequence from a pig isolate in Norway (GenBank: EF012374) with the exception of three polymorphisms, one of which was non-synonymous. SSU, actin, and HSP70 sequences from the faeces of positive pigs were $100 \%$ identical to sequences from isolates used for infection. Neighbour joining, maximum likelihood, and maximum parsimony trees constructed from SSU, actin, and HS70 sequences support the placement of $C$. scrofarum in a cluster with $C$. ryanae, C. xiaoi, and C. bovis (Figure 2).

\subsection{Oocyst morphology}

Oocysts of $C$. scrofarum were similar in size to C. parvum, measuring 4.81-5.96 $\mu \mathrm{m}$ (mean $=5.16) \times 4.23-5.29 \mu \mathrm{m}($ mean $=4.83)$ with a length-to-width ratio of $1.07 \pm 0.06(\mathrm{n}=$ $4 \times 100$ ) (Fig. 3A and Table 3). Oocysts of $C$. scrofarum recovered from infected pigs were morphologically similar to those used for infection (Table 3). Oocysts in faecal smears showed typical Cryptosporidium ACMV staining characteristics (Fig. 3B). Fixed $C$. scrofarum oocysts labelled with FITC conjugated anti-Cryptosporidium oocyst wall antibody and examined by epifluorescence microscopy displayed typical apple green, halolike fluorescence (Fig. 3C).

\section{Discussion}

Based on morphology, C. scrofarum oocysts obtained from naturally and experimentally infected pigs in the present study were indistinguishable from $C$. parvum and larger than oocysts of $C$. bovis $(4.89 \times 4.63 \mu \mathrm{m})$, C. ryanae $(3.16 \times 3.73 \mu \mathrm{m})$, and $C$. xiaoi $(3.94 \times 3.44$ $\mu \mathrm{m})$ (Fayer and Santin, 2009; Fayer et al., 2005, 2008). Other $C$. scrofarum oocyst characteristics including wall thickness and inner structure were not different from the $C$. parvum oocysts examined in this or other studies (Upton and Current, 1985; Vítovec et al., 2006).

It is unclear whether C. scrofarum can be distinguished from C. suis, the other pig-adapted species, based on oocyst morphology alone. Ryan et al. (2004) reported that $C$. suis oocysts had a similar morphology to C. parvum; however, Vítovec et al. (2006) found that $C$. suis oocysts were larger than C. parvum and, by extension, would be larger than C. scrofarum.

Cryptosporidium scrofarum, previously named Cryptosporidium pig genotype II, has been detected in domestic pigs and wild boars in at least 19 countries (see introduction). Most reported infections have been in pigs, with the exception of sporadic infections in a human, a calf, and Western school whiting (Kváč et al., 2009b; Ng et al., 2011; Reid et al., 2010). We have shown that a number of rodents are not susceptible to experimental infection with $C$. scrofarum. These data collectively support a conclusion that $C$. scrofarum is relatively specific for pigs. Furthermore, experimental data from the present study show that 8-weekold but not 4-week-old pigs are susceptible to infection. These data verify the age specificity hypothesis that was predicated on molecular epidemiology studies (Jeníková et al., 2011; Johnson et al., 2008; Kváč et al., 2009a,c; Langkjær et al., 2007).

Cryptosporidium scrofarum has a prepatent period of 4-6 DPI, which is longer than the prepatent periods observed in its closest relatives including C.xiaoi (7-8 DPI), C. ryanae (11 DPI), and C. bovis (16 DPI) (Fayer and Santin, 2009; Fayer et al., 2008; Fayer et al., 2005). The reported prepatent period of $C$. suis in pigs ranges from 2-9 days (Enemark et al., 2003; Vítovec et al., 2006; Xiao et al., 1994). In agreement with previous observations, pigs infected with $C$. scrofarum showed no clinical signs of disease. Similar to $C$. ryanae, $C$. 
scrofarum infections are characterised by shedding of a low number of oocysts (Fayer et al., 2008).

Phylogenetic analyses based on SSU, actin and HSP70 gene sequences show that $C$. scrofarum is genetically distinct from $C$. suis and forms a cluster with $C$. ryanae, $C$. bovis and $C$. xiaoi. At the SSU locus, $C$. scrofarum is $97.3 \%, 97.4 \%$, and $97.6 \%$ similar to $C$. ryanae, $C$. xiaoi, and C. bovis, respectively. In contrast, $C$. scrofarum and $C$. suis are only 92.9\% similar at the SSU locus. These similarities are less than the similarities between recognized Cryptosporidium species including $C$. andersoni and $C$. muris $(99.1 \%$ at the $\mathrm{SSU}$ locus), and $C$. parvum and $C$. tyzzeri ( $99.0 \%$ at the SSU locus). At the actin locus, $C$. scrofarum was $85.3 \%, 87.0 \%, 87.2 \%$, and $86.6 \%$ similar to C. suis, C. ryanae, C. xiaoi, and C. bovis, respectively. This compares to the $99.0 \%$ similarity between $C$. andersoni and $C$. muris and $99.1 \%$ similarity between $C$. parvum and $C$. tyzzeri. At the HSP70 locus, $C$. scrofarum was $81.1 \%, 86.6 \%, 88.2 \%$, and $87.3 \%$ similar to C. suis, C. ryanae, C.xiaoi, and $C$. bovis, respectively. This compares to the $98.1 \%$ similarity between $C$. andersoni and $C$. muris and the $99.3 \%$ similarity between $C$. parvum and $C$. tyzzeri at this locus.

In conclusion, oocyst morphology, nucleotide sequence, and infectivity data demonstrate significant biological and taxonomic differences between Cryptosporidium pig genotype II and recognized Cryptosporidium species. According to ICZN and criteria for naming Cryptosporidium species (Xiao et al., 2004) we propose the name Cryptosporidium scrofarum.

\section{Taxonomic summary}

\section{Cryptosporidium scrofarum $\mathbf{n}$. sp.}

Diagnosis: Oocysts are shed in faeces fully sporulated. Sporulated oocysts $(\mathrm{n}=4 \times 100)$ measure 4.81-5.96 $\mu \mathrm{m}($ mean $=5.16) \times 4.23-5.29 \mu \mathrm{m}($ mean $=4.83)$ with a length-to-width ratio of $1.07 \pm 0.06$. Four sporozoites are present in each oocyst. Endogenous stages are unknown.

Type host: Pig (Sus scrofa).

Other natural hosts: Human (Homo sapiens) (Kváč et al., 2009b), calf (Bos taurus) (Ng et al., 2011), wild boar (Sus scrofa) (Němejc et al., 2012), and Western school whiting (Sillago vittata) (Reid et al., 2010).

Experimental transmission: Attempts to infect common laboratory mice (Mus musculus), Mongolian gerbils (Meriones unguiculatus), southern multimammate mice (Mastomys coucha), yellow-necked mice (Apodemus flavicollis), and guinea pigs (Cavia porcellus) were unsuccessful.

Prepatent period: 4-6 days (this study).

Patent period: More than 30 days (this study).

Age specificity: Cryptosporidium scrofarum n. sp. is infectious for post-weaned piglets only (this study).

Type locality: Czech Republic.

Other localities: Worldwide.

Site of infection: Duodenum, jejunum, ileum, caecum, and colon. 
Material deposited: A phototype, description of oocysts and DNA are deposited at the Institute of Parasitology, Biology Centre of the Academy of Sciences of the Czech Republic.

DNA sequences: partial sequences of SSU, actin, and HSP70 genes were submitted to GenBank under the accession numbers JX424840, JX424841, and JX424842, respectively.

Etymology: this species was first named Cryptosporidium scrofarum from the Latin noun "scrofa" (meaning a breeding sow) according to ICZN Article 11.9.1-3 as a plural in the genitive case; as it appears to be adapted to adult pigs.

\section{Acknowledgments}

The authors would like to thank Pavla Vandasová, Lenka Hlásková, and Cathy Giddings for expert technical assistance. Special thanks also go to the farmers for their participation. The authors would like to especially thank Jana Karlíčková for assistance during the breeding of pigs. This study was funded by projects from the Ministry of Education, Youth and Sports of the Czech Republic (LH11061 and MSM 6007665806), the Grant Agency of University of South Bohemia (022/2010/Z) and NIH Grant Number 2P20 RR015566 from the National Center for Research Resources.

\section{References}

Adesiyun AA, Kaminjolo JS, Ngeleka M, Mutani A, Borde G, Harewood W, Harper W. A longitudinal study on enteropathogenic infections of livestock in Trinidad. Rev. Soc. Bras. Med. Trop. 2001; 34:29-35. [PubMed: 11340494]

Arrowood MJ, Sterling CR. Isolation of Cryptosporidium oocysts and sporozoites using discontinuous sucrose and isopycnic Percoll gradients. J. Parasitol. 1987; 73:314-319. [PubMed: 3585626]

Atwill ER, Sweitzer RA, Pereira MG, Gardner IA, Van VD, Boyce WM. Prevalence of and associated risk factors for shedding Cryptosporidium parvum oocysts and Giardia cysts within feral pig populations in California. Appl. Environ. Microbiol. 1997; 63:3946-3949. [PubMed: 9327560]

Bergeland ME. Necrotic enteritis in nursing piglets. American Association of Veterinary Laboratory Diagnosticians. 1977; 20:151-158.

Bilic HR, Bilkei G. Balantidium, Cryptosporidium and Giardia species infections in indoor and outdoor pig production units in Croatia. Vet. Rec. 2006; 158:61. [PubMed: 16415236]

Budu-Amoako E, Greenwood SJ, Dixon BR, Barkema HW, Hurnik D, Estey C, McClure JT. Occurrence of Giardia and Cryptosporidium in pigs on Prince Edward Island, Canada. Vet. Parasitol. 2012; 184:18-24. [PubMed: 21868167]

Canestri Trotti G, Pampiglione S, Visconti S. Cryptosporidium sp. and Isospora suis in swine in Italy. Parassitologia. 1984; 26:299-304. [PubMed: 6600003]

Chen Z, Mi R, Yu H, Shi Y, Huang Y, Chen Y, Zhou P, Cai Y, Lin J. Prevalence of Cryptosporidium spp. in pigs in Shanghai, China. Vet. Parasitol. 2011; 181:113-119. [PubMed: 21616599]

Ebeid M, Mathis A, Pospischil A, Deplazes P. Infectivity of Cryptosporidium parvum genotype I in conventionally reared piglets and lambs. Parasitol. Res. 2003; 90:232-235. [PubMed: 12783313]

Enemark HL, Ahrens P, Bille-Hansen V, Heegaard PM, Vigre H, Thamsborg SM, Lind P. Cryptosporidium parvum : infectivity and pathogenicity of the 'porcine' genotype. Parasitology. 2003; 126:407-416. [PubMed: 12793644]

Epe C, Coati N, Schnieder T. Results of parasitological examinations of faecal samples from horses, ruminants, pigs, dogs, cats, hedgehogs and rabbits between 1998 and 2002. Dtsch. Tierarztl. Wochenschr. 2004; 111:243-247. [PubMed: 15287577]

Farzan A, Parrington L, Coklin T, Cook A, Pintar K, Pollari F, Friendship R, Farber J, Dixon B. Detection and characterization of Giardia duodenalis and Cryptosporidium spp. on swine farms in Ontario, Canada. Foodborne Pathog Dis. 2011; 8:1207-1213. [PubMed: 21675863]

Fayer R, Santin M. Cryptosporidium xiaoi n. sp. (Apicomplexa: Cryptosporidiidae) in sheep (Ovis aries). Vet. Parasitol. 2009; 164:192-200. [PubMed: 19501967]

Fayer R, Santin M, Trout JM. Cryptosporidium ryanae n. sp. (Apicomplexa: Cryptosporidiidae) in cattle (Bos taurus). Vet. Parasitol. 2008; 156:191-198. [PubMed: 18583057] 
Fayer R, Santin M, Xiao L. Cryptosporidium bovis n. sp. (Apicomplexa: Cryptosporidiidae) in cattle (Bos taurus). J. Parasitol. 2005; 91:624-629. [PubMed: 16108557]

Featherstone CA, Marshall JA, Giles M, Sayers AR, Pritchard GC. Cryptosporidium species infection in pigs in East Anglia. Vet. Rec. 2010; 166:51-52. [PubMed: 20064979]

Fiuza VR, Gallo SS, Frazao-Teixeira E, Santin M, Fayer R, Oliveira FC. Cryptosporidium pig genotype II diagnosed in pigs from the state of Rio De Janeiro, Brazil. J. Parasitol. 2011; 97:146147. [PubMed: 21348623]

Guselle NJ, Appelbee AJ, Olson ME. Biology of Cryptosporidium parvum in pigs: from weaning to market. Vet. Parasitol. 2003; 113:7-18. [PubMed: 12651214]

Hamnes IS, Gjerde BK, Forberg T, Robertson LJ. Occurrence of Cryptosporidium and Giardia in suckling piglets in Norway. Vet. Parasitol. 2007; 144:222-233. [PubMed: 17123737]

Hsu BM, Wun HY, Hsu CL. Detection and species identification of Cryptosporidium from Taiwan feeding animals. J. Parasitol. 2008; 94:252-256. [PubMed: 18372647]

Izumiyama S, Furukawa I, Kuroki T, Yamai S, Sugiyama H, Yagita K, Endo T. Prevalence of Cryptosporidium parvum infections in weaned piglets and fattening porkers in Kanagawa Prefecture, Japan. Jpn J Infect Dis. 2001; 54:23-26. [PubMed: 11326125]

Jeníková M, Němejc K, Sak B, Květoňová D, Kváč M. New view on the age-specificity of pig Cryptosporidium by species-specific primers for distinguishing Cryptosporidium suis and Cryptosporidium pig genotype II. Vet. Parasitol. 2011; 176:120-125. [PubMed: 21131129]

Jiang J, Alderisio KA, Xiao L. Distribution of Cryptosporidium genotypes in storm event water samples from three watersheds in New York. Appl. Environ. Microbiol. 2005; 71:4446-4454. [PubMed: 16085835]

Johnson J, Buddle R, Reid S, Armson A, Ryan UM. Prevalence of Cryptosporidium genotypes in pre and post-weaned pigs in Australia. Exp. Parasitol. 2008; 119:418-421. [PubMed: 18486131]

Kennedy GA, Kreitner GL, Strafuss AC. Cryptosporidiosis in three pigs. J. Am. Vet. Med. Assoc. 1977; 170:348-350. [PubMed: 833036]

Kilani RT, Sekla L. Purification of Cryptosporidium oocysts and sporozoites by cesium chloride and Percoll gradients. Am. J. Trop. Med. Hyg. 1987; 36:505-508. [PubMed: 3034085]

Kváč M, Hanzlíková D, Sak B, Květoňová D. Prevalence and age-related infection of Cryptosporidium suis, C. muris and Cryptosporidium pig genotype II in pigs on a farm complex in the Czech Republic. Vet. Parasitol. 2009a; 160:319-322.

Kváč M, Kestřánová M, Květoňová D, Kotková M, Ortega Y, McEvoy J, Sak B. Cryptosporidium tyzzeri and Cryptosporidium muris originated from wild West-European house mice (Mus musculus domesticus) and East-European house mice (Mus musculus musculus) are noninfectious for pigs. Exp. Parasitol. 2012; 131:107-110. [PubMed: 22465334]

Kváč M, Květoňová D, Sak B, Ditrich O. Cryptosporidium pig genotype II in immunocompetent man. Emerg. Infect. Dis. 2009b; 15:982-983.

Kváč M, Květoňová D, Salát J, Ditrich O. Viability staining and animal infectivity of Cryptosporidium andersoni oocysts after long-term storage. Parasitol. Res. 2007a; 100:213-217.

Kváč M, Ondráčková Z, Květoňová D, Sak B, Vítovec J. Infectivity and pathogenicity of Cryptosporidium andersoni to a novel host, southern multimammate mouse (Mastomys coucha). Vet. Parasitol. 2007a; 143:229-233.

Kváč M, Sak B, Hanzlíková D, Kotilová J, Květoňová D. Molecular characterization of Cryptosporidium isolates from pigs at slaughterhouses in South Bohemia, Czech Republic. Parasitol. Res. 2009c; 104:425-428.

Kváč M, Vítovec J. Prevalence and pathogenicity of Cryptosporidium andersoni in one herd of beef cattle. Journal of veterinary medicine. B, Infectious diseases and veterinary public health. 2003; 50:451-457.

Langkjær RB, Vigre H, Enemark HL, Maddox-Hyttel C. Molecular and phylogenetic characterization of Cryptosporidium and Giardia from pigs and cattle in Denmark. Parasitology. 2007; 134:339350. [PubMed: 17076923]

Maddox-Hyttel C, Langkjær RB, Enemark HL, Vigre H. Cryptosporidium and Giardia in different age groups of Danish cattle and pigs--occurrence and management associated risk factors. Vet. Parasitol. 2006; 141:48-59. [PubMed: 16797848] 
McCarthy S, Ng J, Gordon C, Miller R, Wyber A, Ryan UM. Prevalence of Cryptosporidium and Giardia species in animals in irrigation catchments in the southwest of Australia. Exp. Parasitol. 2008; 118:596-599. [PubMed: 18068157]

Miláček P, Vítovec J. Differential staining of cryptosporidia by aniline-carbol-methyl violet and tartrazine in smears from feces and scrapings of intestinal mucosa. Folia Parasitol. (Praha). 1985; 32:50. [PubMed: 2580763]

Moon HW, Bemrick WJ. Fecal transmission of calf cryptosporidia between calves and pigs. Vet. Pathol. 1981; 18:248-255. [PubMed: 7467084]

Morgan UM, Monis PT, Fayer R, Deplazes P, Thompson RC. Phylogenetic relationships among isolates of Cryptosporidium: evidence for several new species. J. Parasitol. 1999; 85:1126-1133. [PubMed: 10647047]

Morgan UM, Monis PT, Xiao L, Limor J, Sulaiman I, Raidal S, O'Donoghue P, Gasser R, Murray A, Fayer R, Blagburn BL, Lal AA, Thompson RC. Molecular and phylogenetic characterisation of Cryptosporidium from birds. Int. J. Parasitol. 2001; 31:289-296. [PubMed: 11226456]

Němejc K, Sak B, Květoňová D, Hanzal V, Jeníková M, Kváč M. The first report on Cryptosporidium suis and Cryptosporidium pig genotype II in Eurasian wild boars (Sus scrofa) (Czech Republic). Vet. Parasitol. 2012; 184:122-125. [PubMed: 21917378]

$\mathrm{Ng}$ J, Yang R, McCarthy S, Gordon C, Hijjawi N, Ryan U. Molecular characterization of Cryptosporidium and Giardia in pre-weaned calves in Western Australia and New South Wales. Vet. Parasitol. 2011; 176:145-150. [PubMed: 21130578]

Nunez A, McNeilly F, Perea A, Sanchez-Cordon PJ, Huerta B, Allan G, Carrasco L. Coinfection by Cryptosporidium parvum and porcine circovirus type 2 in weaned pigs. J Vet Med B Infect Dis Vet Public Health. 2003; 50:255-258. [PubMed: 12864903]

Olson ME, Thorlakson CL, Deselliers L, Morck DW, McAllister TA. Giardia and Cryptosporidium in Canadian farm animals. Vet. Parasitol. 1997; 68:375-381. [PubMed: 9106959]

Quilez J, Sanchez-Acedo C, Clavel A, del Cacho E, Lopez-Bernad F. Comparison of an acid-fast stain and a monoclonal antibody-based immunofluorescence reagent for the detection of Cryptosporidium oocysts in faecal specimens from cattle and pigs. Vet. Parasitol. 1996; 67:75-81. [PubMed: 9011016]

Reid A, Lymbery A, Ng J, Tweedle S, Ryan U. Identification of novel and zoonotic Cryptosporidium species in marine fish. Vet. Parasitol. 2010; 168:190-195. [PubMed: 20031326]

Reinoso R, Becares E. The occurrence of intestinal parasites in swine slurry and their removal in activated sludge plants. Bioresour. Technol. 2008; 99:6661-6665. [PubMed: 18180154]

Rhee JK, Seu YS, Park BK. Isolation and identification of Cryptosporidium from various animals in Korea. III. Identification of Cryptosporidium baileyi from Korean chicken. Kisaengchunghak Chapchi. 1991; 29:315-324. [PubMed: 1804296]

Ryan UM, Monis P, Enemark HL, Sulaiman I, Samarasinghe B, Read C, Buddle R, Robertson I, Zhou L, Thompson RC, Xiao L. Cryptosporidium suis n. sp. (Apicomplexa: Cryptosporidiidae) in pigs (Sus scrofa). J. Parasitol. 2004; 90:769-773. [PubMed: 15357067]

Ryan UM, Samarasinghe B, Read C, Buddle JR, Robertson ID, Thompson RC. Identification of a novel Cryptosporidium genotype in pigs. Appl. Environ. Microbiol. 2003; 69:3970-3974. [PubMed: 12839769]

Sanford SE. Enteric cryptosporidial infection in pigs: 184 cases (1981-1985). J. Am. Vet. Med. Assoc. 1987; 190:695-698. [PubMed: 3570923]

Sauch JF, Flanigan D, Galvin ML, Berman D, Jakubowski W. Propidium iodide as an indicator of Giardia cyst viability. Appl. Environ. Microbiol. 1991; 57:3243-3247. [PubMed: 1723585]

Tacal JV Jr, Sobieh M, el-Ahraf A. Cryptosporidium in market pigs in southern California, USA. Vet. Rec. 1987; 120:615-616. [PubMed: 3629872]

Tamura K, Peterson D, Peterson N, Stecher G, Nei M, Kumar S. MEGA5: molecular evolutionary genetics analysis using maximum likelihood, evolutionary distance, and maximum parsimony methods. Mol. Biol. Evol. 2011; 28:2731-2739. [PubMed: 21546353]

Tzipori S, Smith M, Makin T, Halpin C. Enterocolitis in piglets caused by Cryptosporidium sp. purified from calf faeces. Vet. Parasitol. 1982; 11:121-126. [PubMed: 6819679] 
Upton SJ, Current WL. The species of Cryptosporidium (Apicomplexa: Cryptosporidiidae) infecting mammals. J. Parasitol. 1985; 71:625-629. [PubMed: 4057006]

Villacorta I, Ares-Mazas E, Lorenzo MJ. Cryptosporidium parvum in cattle, sheep and pigs in Galicia (N.W. Spain). Vet. Parasitol. 1991; 38:249-252. [PubMed: 1858293]

Vítovec J, Hamadejová K, Landová L, Kváč M, Květoňová D, Sak B. Prevalence and pathogenicity of Cryptosporidium suis in pre- and post-weaned pigs. J Vet Med B Infect Dis Vet Public Health. 2006; 53:239-243. [PubMed: 16732883]

Vítovec J, Koudela B. Pathogenesis of intestinal cryptosporidiosis in conventional and gnotobiotic piglets. Vet. Parasitol. 1992; 43:25-36. [PubMed: 1496800]

Wang R, Qiu S, Jian F, Zhang S, Shen Y, Zhang L, Ning C, Cao J, Qi M, Xiao L. Prevalence and molecular identification of Cryptosporidium spp. in pigs in Henan, China. Parasitol. Res. 2010; 107:1489-1494. [PubMed: 20697908]

Wieler LH, Ilieff A, Herbst W, Bauer C, Vieler E, Bauerfeind R, Failing K, Klos H, Wengert D, Baljer $\mathrm{G}$, Zahner H. Prevalence of enteropathogens in suckling and weaned piglets with diarrhoea in southern Germany. J Vet Med B Infect Dis Vet Public Health. 2001; 48:151-159. [PubMed: 11315526]

Xiao L, Escalante L, Yang C, Sulaiman I, Escalante AA, Montali RJ, Fayer R, Lal AA. Phylogenetic analysis of Cryptosporidium parasites based on the small-subunit rRNA gene locus. Appl. Environ. Microbiol. 1999; 65:1578-1583. [PubMed: 10103253]

Xiao L, Fayer R, Ryan U, Upton SJ. Cryptosporidium taxonomy: recent advances and implications for public health. Clin. Microbiol. Rev. 2004; 17:72-97. [PubMed: 14726456]

Xiao L, Herd RP, Bowman GL. Prevalence of Cryptosporidium and Giardia infections on two Ohio pig farms with different management systems. Vet. Parasitol. 1994; 52:331-336. [PubMed: 8073616]

Xiao L, Moore JE, Ukoh U, Gatei W, Lowery CJ, Murphy TM, Dooley JS, Millar BC, Rooney PJ, Rao JR. Prevalence and identity of Cryptosporidium spp. in pig slurry. Appl. Environ. Microbiol. 2006; 72:4461-4463. [PubMed: 16751569]

Yatswako S, Faleke OO, Gulumbe ML, Daneji AI. Cryptosporidium oocysts and Balantidium coli cysts in pigs reared semi-intensively in Zuru, Nigeria. Pak J Biol Sci. 2007; 10:3435-3439. [PubMed: 19090165]

Yin J, Shen Y, Yuan Z, Lu W, Xu Y, Cao J. Prevalence of the Cryptosporidium pig genotype II in pigs from the Yangtze River Delta, China. PLoS One. 2011; 6:e20738. [PubMed: 21677776]

Zintl A, Neville D, Maguire D, Fanning S, Mulcahy G, Smith HV, De Waal T. Prevalence of Cryptosporidium species in intensively farmed pigs in Ireland. Parasitology. 2007; 134:15751582. [PubMed: 17565758] 


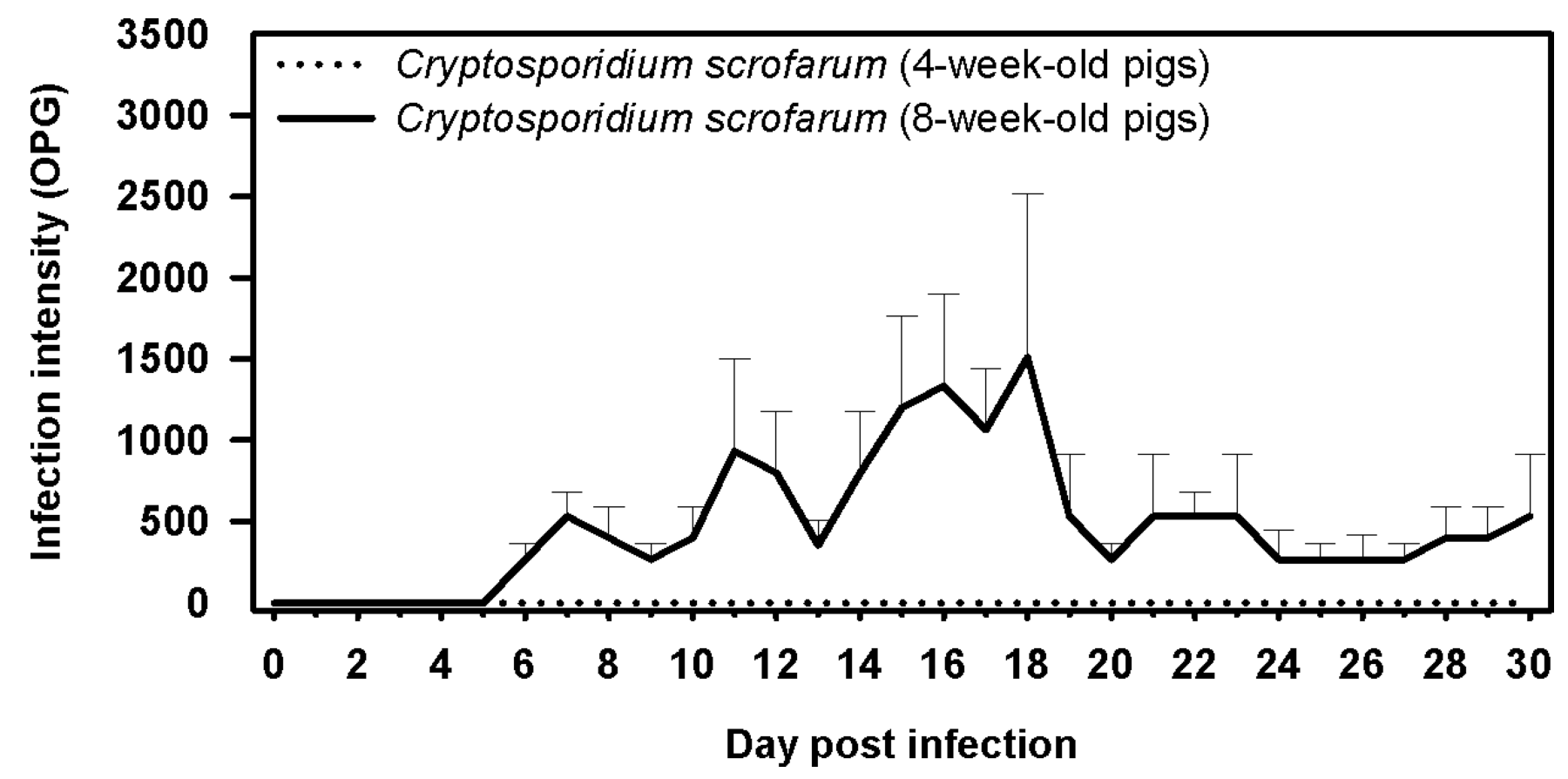

Figure 1.

Course of infection of Cryptosporidium scrofarum in 4- and 8-week-old pigs based on coprological examination of faeces. 

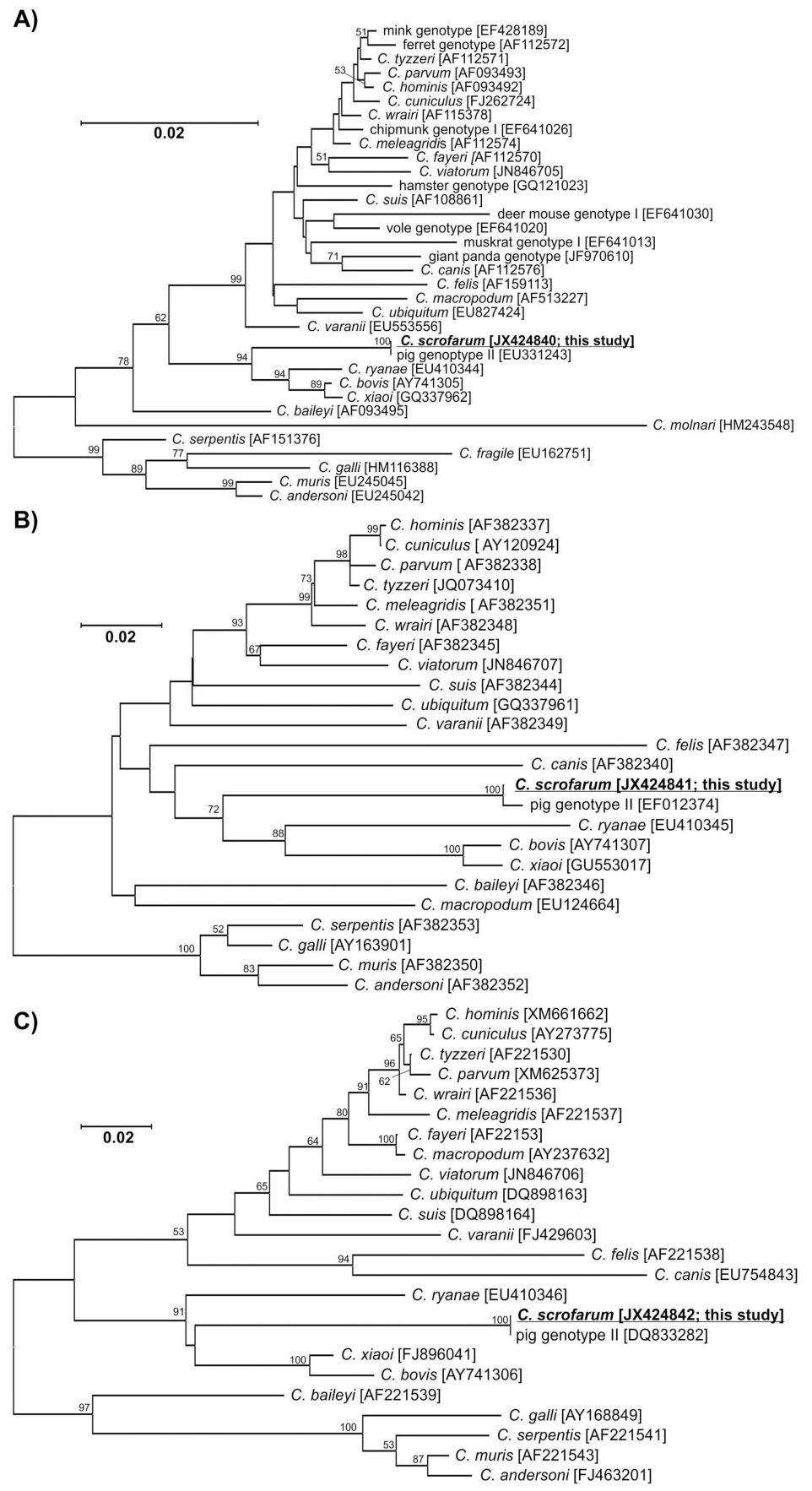

Figure 2.

Phylogenetic relationships between Cryptosporidium scrofarum (highlighted and underlined) and other Cryptosporidium spp. as inferred by a neighbour-joining analysis of A) the SSU ( 753 base positions in the final dataset), B) actin (586 base positions in the final dataset) and C) Heat Shock Protein 70 (323 base positions in the final dataset) genes. The percentage of replicate trees in which the associated taxa clustered together in the bootstrap test (1,000 replicates). Numbers at the nodes represent bootstrap values for the nodes gaining more than $50 \%$ support. Scale bar included in each tree. 


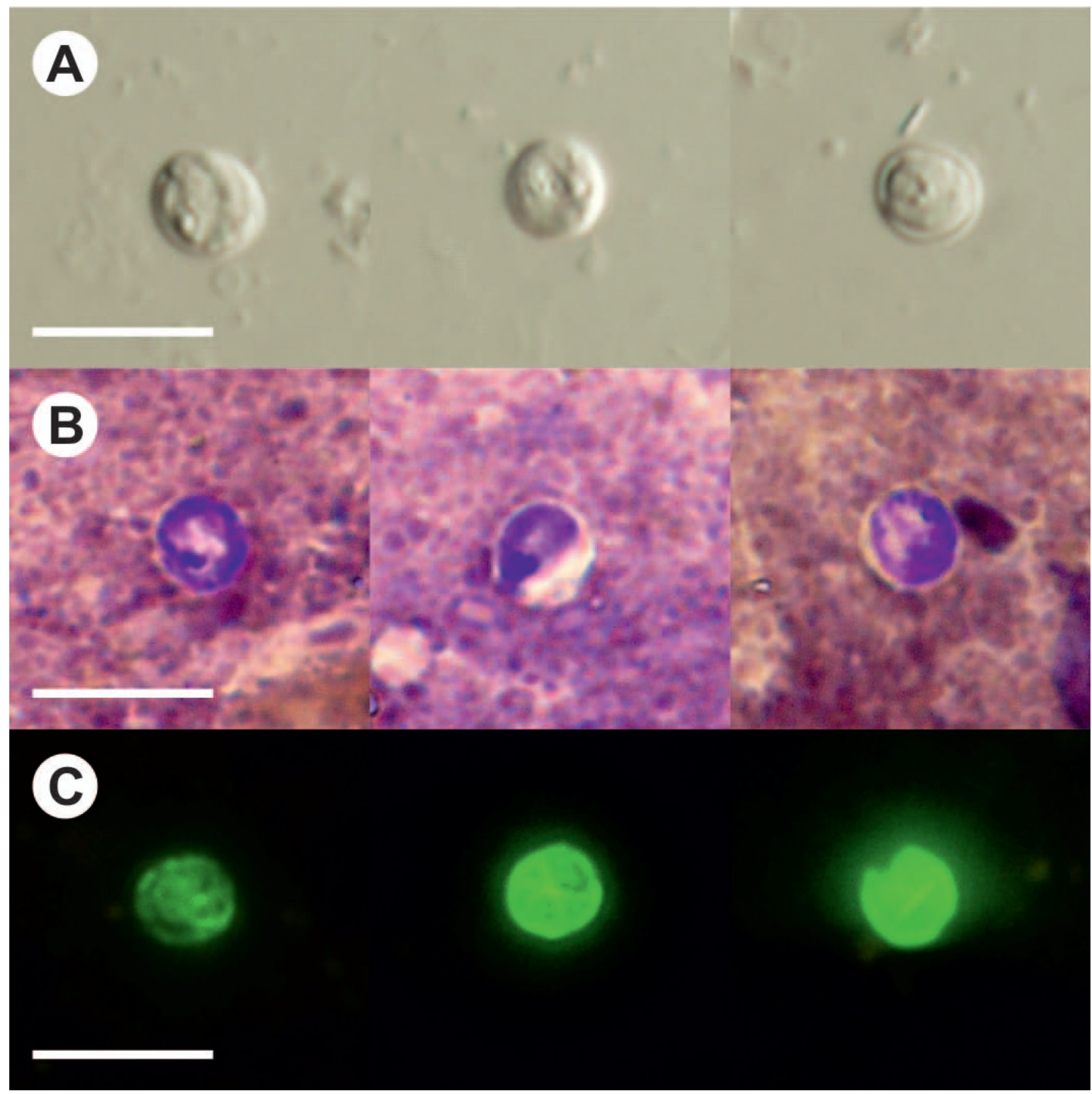

Figure 3.

Cryptosporidium scrofarum oocysts in A) differential interference contrast microscopy and stained by B) aniline-carbol-methyl violet and C) anti-Cryptosporidium FITC-conjugated antibody. Bar $=10 \mu \mathrm{m}$. 


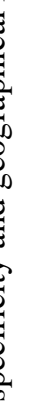

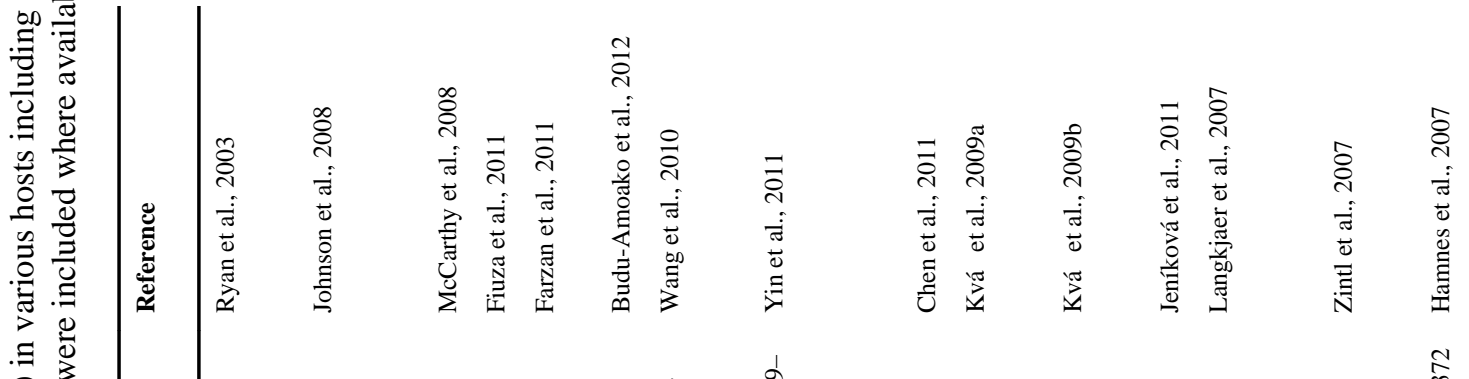

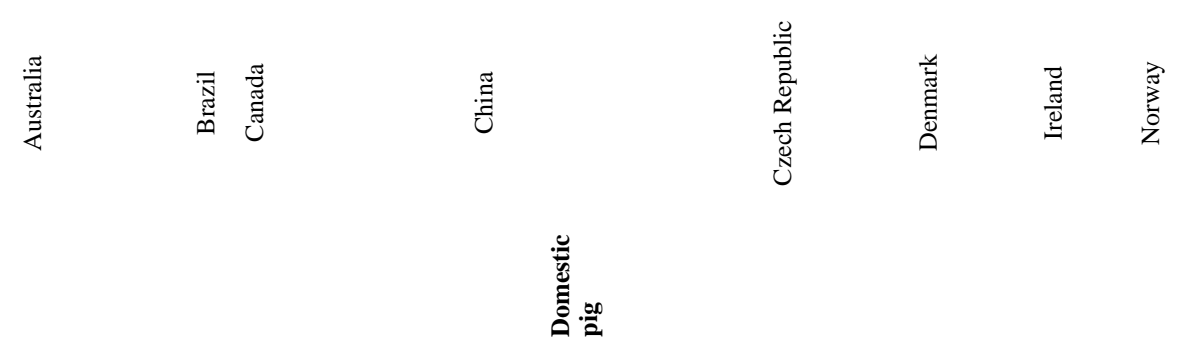




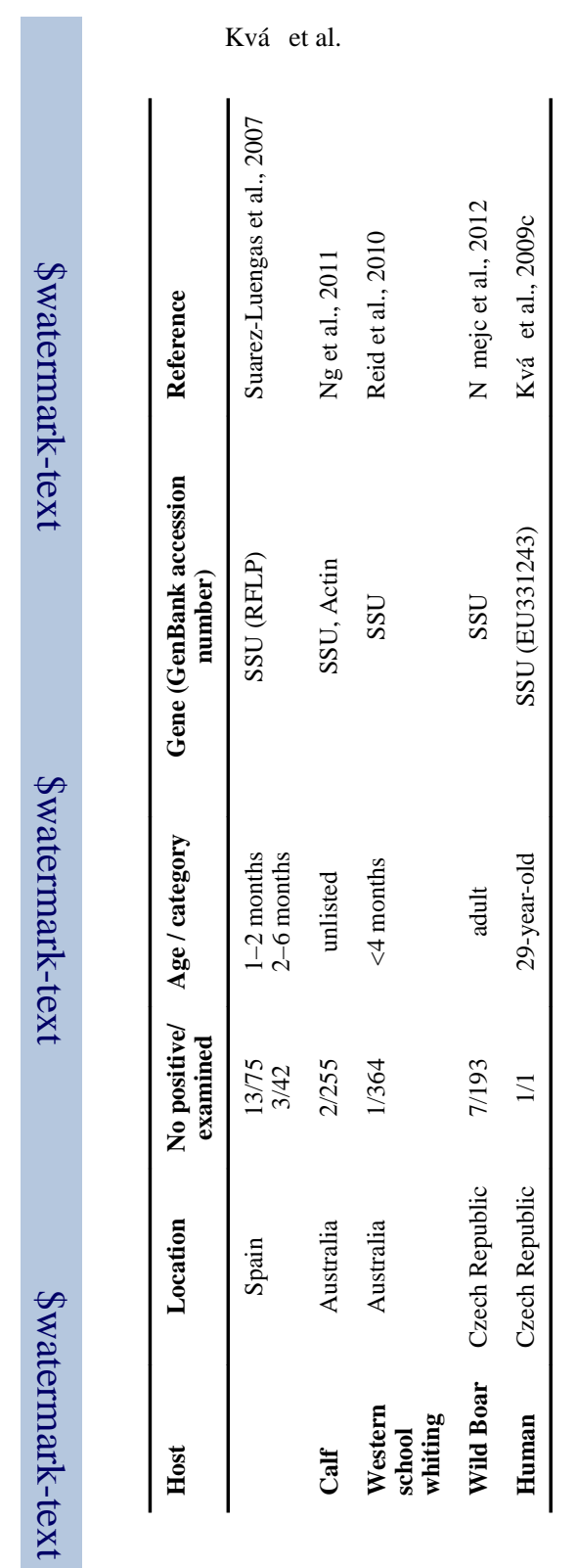

Page 16 


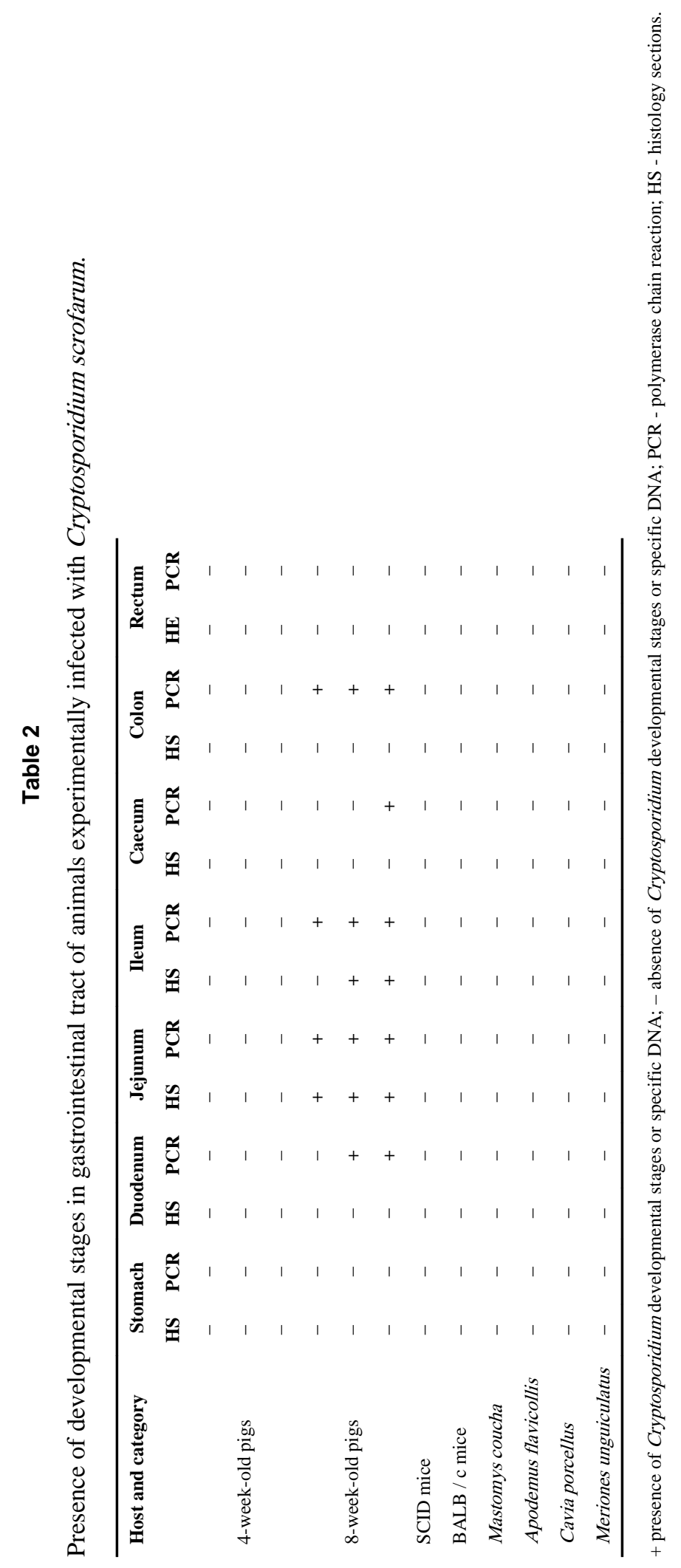

Vet Parasitol. Author manuscript; available in PMC 2014 January 31. 
